\title{
Comparison of semi-automatized assays for anti-T. gondii IgG detection in low-reactivity serum samples: importance of the results in patient counseling
}

Comparação de ensaios semi-automatizados para pesquisa de IgG anti-T. gondii em amostras de soros de baixa reatividade: importância dos resultados no aconselhamento do paciente

\author{
Paulo Guilherme Leser ${ }^{1}$ \\ Lúcia Sivieri de Assis Rocha ${ }^{1}$ \\ Maria Emília Germani Moura ${ }^{1}$ \\ Antonio Walter Ferreira ${ }^{2}$
}

\begin{tabular}{l|l}
\multicolumn{1}{c|}{ key words } & a $\mathbf{l}$ tract \\
Toxoplasmosis & $\begin{array}{l}\text { Toxoplasmosis is a disease which can cause severe congenital infection and is normally } \\
\text { Immunodiagnosis }\end{array}$ \\
Pregnancy & $\begin{array}{l}\text { Several different tests allow to distinguish recent from past infections and to quantify anti-T. } \\
\text { gondii specific IgG, and the results can be used as markers for immunity. In the present study, } \\
\text { we compare the performance of two different methodologies, the Elfa (bioMérieux S.A) and } \\
\text { the Meia (Abbott Laboratories) in detecting T. gondii specific IgG in low-reactivity sera. Of 76 } \\
\text { analyzed samples, three presented discrepant results, being positive in the Abbott AxSYM } \\
\text { Toxo IgG assay, and negative in the bioMérieux Vidas Toxo IgG II assay. By using other tests, } \\
\text { the three sera were confirmed to be negative. The results are discussed in the context of their } \\
\text { importance for patient management, especially during pregnancy. }\end{array}$
\end{tabular}

Toxoplasmose, doença conhecida por sua severidade na infecção congênita é geralmente diagnosticada pela demonstração de anticorpos específicos contra antígenos de T. gondii, presentes no soro de indivíduos infectados. Diferentes testes são disponíveis para diferenciar infecção recente de infecção pregressa, para quantificar anticorpos IgG anti-T. gondii nos soros dos pacientes e utilizar os resultados como marcadores de imunidade. Neste trabalho apresentamos os resultados do estudo comparativo de duas tecnologias, Elfa (bioM érieux S.A.) e M eia (Abbott Laboratories), para pesquisa de anticorpos IgG anti-T. gondii em amostras de soros de baixa reatividade. De 76 amostras processadas, três apresentaram resultados discrepantes, reagentes para AXSYM Toxo IgG e não-reagentes para Vidas Toxo IgG II. A confirmação doS resultados, feita por bateria de testes, mostrou que todas as três amostras eram não-reagentes.

Os resultados são discutidos em sua importância e orientação clínica, principalmente para a unitermos

paciente gestante.

\section{Introduction}

Toxoplasmosis caused by Toxoplasma gondii is a disease distributed worldwide, affecting almost $60 \%$ of the European population, $70 \%$ of the people living in the Americas, and $75 \%$ of the African and Asian populations.

Apart from its form acquired by contact with cysts from the environment, toxoplasmosis is the main pathology associated with pathologies of the fetus and premature abortions. Therefore, it is necessary to investigate the use of safe diagnostic methods that allow distinguishing recent from past infections, and seropositive from seronegative individuals.

Over years, laboratory diagnosis was performed using the traditional serologic profile of toxoplasmosis, 
as described by Camargo, Desmonts and Remington. This procedure has been widely propagated in medical schools and scientific meetings (4). The development of enzymeimmunoassays and the technical variations following the automation of the procedures led to the production of very sensitive assays for $\mathrm{T}$. gondii specific $\lg \mathrm{G}$ and $\lg \mathrm{M}$ detection (3). Since anti-T. gondii specific IgM persists over long periods in the serum, researchers started to review the old concepts and to introduce tests that rely on the avidity of specific $\lg G$ to serologically distinguish patients with an acute infection from those with past infections, that is, from patients that still have residual specific lgM but without clinical significance (7).

On the other hand, the detection of anti-T. gondii IgG is considered to be a marker for immunity and is very important as a reference for clinical and epidemiological patient management and counseling.

In many health care services, the detection of anti-T. gondii specific IgG implicates that the patient is considered protected against the disease in case of a new contact with the parasite. Consequently, the specificity of assays that detect specific $\lg \mathrm{G}$ is of vital importance, and several investigations on this diagnostic approach are under way.

In the present study we compare the performance of two automated assays, the AxSYM Toxo IgG assay (Abbott Laboratories) and the Vidas Toxo IgG II assay (bioMérieux S.A.), employing a panel of low-reactive serum samples that were selected after routine screening in a laboratory of clinical analyses. All samples were analyzed with an indirect immunofluorescence assay and a passive hemagglutination test.

\section{Material and methods}

\section{Serum samples}

For the study, we selected 76 serum samples that were weakly reactive in a semi-automated assay for $\mathrm{T}$. gondiispecific $\lg G$, the AxSYM Toxo $\lg G$ assay. The sera were selected from samples routinely collected for serology in the immunology sector of the Fleury Laboratory for clinical analyses. All sera were stored at $-20^{\circ} \mathrm{C}$ or $-80^{\circ} \mathrm{C}$ until testing.

\section{Vidas Toxo IgG II (bioMérieux S.A.)}

This assay is semi-automated and permits the quantification of $\mathrm{T}$. gondii specific $\lg \mathrm{G}$ in serum or plasma employing the ELFA (Enzyme-linked fluorescent assay) technology. All samples were analyzed and the results interpreted according to the instructions provided by the manufacturer.

\section{AxSYM Toxo IgG (Abbott Laboratories - Diagnostic Division)}

This semi-automated assay allows for the quantification of T. gondii-specific $\lg \mathrm{G}$ in serum or plasma employing the MEIA (Microparticle enzyme immunoassay) technology. All samples were analyzed and the results interpreted according to the instructions provided by the manufacturer.

\section{Other serologic assays}

Conventional serologic analysis was carried out employing commercial assays for indirect immunofluorescence (IMUNOTOXO and FLUOLINE G, bioMérieux S.A.) and passive hemagglutination (HEMATOXO, bioMérieux S.A.). All tests were carried out following the respective instructions provided by the manufacturer.

\section{Results}

The results are shown in Tables $\mathbf{1}$ and $\mathbf{2}$, and in the Figure.

Table 1 shows the results of 73 serum samples that were positive in both automated assays. The RI values show that the reactivity was higher in the Vidas Toxo IgG II assay, when compared to the AxSYM Toxo IgG assay. The average reactivity of the bioMérieux assay was $39.8 \mathrm{UI} / \mathrm{ml}$, whereas the Abbott assay showed an average reactivity of $15.8 \mathrm{UI} /$ $\mathrm{ml}$. The Figure shows a graphic representation of the reactivity variations for each serum.

Table 2 shows the discrepant results obtained for three sera. The negative results obtained by the Vidas Toxo $\lg C$ II assay were also obtained when repeated in duplicate, and were subsequently confirmed by hemagglutination and indirect immunofluorescence.

\section{Discussion}

In almost all pathologies, serologic assays are widely employed for prevention, diagnosis, and monitoring of patients subjected to specific therapies. Today, in the case of toxoplasmosis, new diagnostic parameters such as $\lg G$ avidity are assessed in order to identify the most likely time of infection and to allow the physician to better evaluate the clinical 
Reactivity indices (in International Units per mililiter $[\mathrm{UI} / \mathrm{ml}]$ ) for all sera by the Vidas Toxo IgG II assay Table 1 and the AxSYM Toxo IgG assay

\begin{tabular}{|c|c|c|c|c|c|}
\hline Sample & AxSYM & Vidas & Sample & AXSYM & Vidas \\
\hline 1 & 26 & 65 & 38 & 13.9 & 78 \\
\hline 2 & 10 & 21 & 39 & 10.8 & 19 \\
\hline 3 & 4 & 12 & 40 & 5.6 & 12 \\
\hline 4 & 8 & 33 & 41 & 18 & 35 \\
\hline 5 & 9.9 & 23 & 42 & 23.1 & 73 \\
\hline 6 & 14.6 & 43 & 43 & 5.4 & 11 \\
\hline 7 & 24 & 45 & 44 & 26.4 & 46 \\
\hline 8 & 9 & 12 & 45 & 26.9 & 57 \\
\hline 9 & 10.2 & 25 & 46 & 13.3 & 33 \\
\hline 10 & 25.7 & 75 & 47 & 22.2 & 50 \\
\hline 11 & 8.9 & 19 & 48 & 18.4 & 47 \\
\hline 12 & 22.1 & 52 & 49 & 18.6 & 45 \\
\hline 13 & 14.5 & 54 & 50 & 8.4 & 4 \\
\hline 14 & 7.9 & 22 & 51 & 22 & 63 \\
\hline 15 & 15.4 & 56 & 52 & 17.4 & 52 \\
\hline 16 & 26.4 & 60 & 53 & 18.7 & 49 \\
\hline 17 & 22 & 65 & 54 & 20 & 48 \\
\hline 18 & 17 & 39 & 55 & 5.6 & 15 \\
\hline 19 & 18.5 & 38 & 56 & 10.8 & 26 \\
\hline 20 & 20.9 & 54 & 57 & 11.3 & 23 \\
\hline 21 & 10.9 & 26 & 58 & 24.2 & 57 \\
\hline 22 & 11.6 & 27 & 59 & 4.3 & 7 \\
\hline 23 & 23.7 & 57 & 60 & 17.7 & 82 \\
\hline 24 & 24.3 & 41 & 61 & 25.1 & 49 \\
\hline 25 & 18.5 & 29 & 62 & 6.8 & 23 \\
\hline 26 & 8.4 & 18 & 63 & 17.2 & 41 \\
\hline 27 & 10.5 & 20 & 64 & 6.6 & 15 \\
\hline 28 & 18.3 & 38 & 65 & 21.3 & 63 \\
\hline 29 & 18.9 & 44 & 66 & 11.7 & 27 \\
\hline 30 & 9.2 & 23 & 67 & 22.3 & 103 \\
\hline 31 & 18.3 & 40 & 68 & 17.6 & 74 \\
\hline 32 & 22.6 & 53 & 69 & 16.9 & 49 \\
\hline 33 & 8.4 & 21 & 70 & 13.3 & 42 \\
\hline 34 & 9.5 & 17 & 71 & 23.3 & 47 \\
\hline 35 & 15.9 & 38 & 72 & 17.5 & 45 \\
\hline 36 & 12.1 & 25 & 73 & 29 & 54 \\
\hline 37 & 5.6 & 10 & Average & 15.79863 & 39.780822 \\
\hline
\end{tabular}

management of each patient $(1,2,6)$. Titers of specific serum antibody were used to differentiate recent and past toxoplasma infections in the classic Sabin-Feldman reaction and, later, by indirect immunofluorescence tests (IIF) which employ as conjugate fluorescein-labeled anti-human Ig sheep serum. However, with these assays almost $20 \%$ of all cases remained undefined because they showed titers that were higher or lower than 1/1000, used as cutoff value for distinguishing

\begin{tabular}{|c|c|c|c|c|}
\hline \multirow{2}{*}{$\begin{array}{l}\text { Table } 2 \\
\text { Sample }\end{array}$} & \multicolumn{4}{|c|}{$\begin{array}{l}\text { Sera with discrepant results in the } \\
\text { Vidas Toxo lgG e AxSYM Toxo IgG } \\
\text { assays }\end{array}$} \\
\hline & AxSYM & Vidas & IFI-IgG & HAI \\
\hline 1 & 3.2 & NR & NR & NR \\
\hline 2 & 15.2 & NR & NR & NR \\
\hline 3 & 4.3 & NR & NR & NR \\
\hline
\end{tabular}

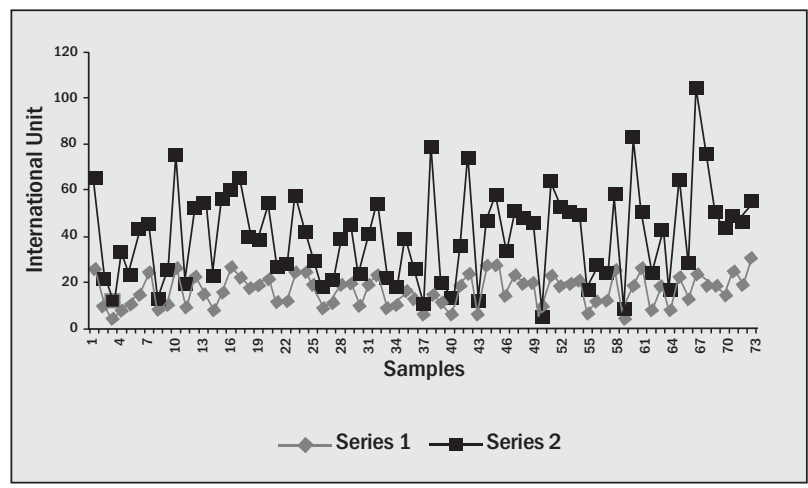

Figure - Reactivity of the serum samples in automated assays

the different phases of toxoplasmosis. In other words, $10 \%$

of the samples obtained from patients with a recent infection had $\lg G$ titers below $1 / 1000$ and, therefore, were diagnosed as having been infected in the past, whereas $10 \%$ of samples obtained from patients with past infections still showed titers higher than 1/1000 and, therefore, were considered recently infected.

Advances in diagnostic methodology permitted the detection and quantification of the different immunoglobulin classes, leading to a more precise diagnosis of recent and past toxoplasma-infections. Over years, T. gondii-specific IgM detected by IIF was considered as an efficient marker of active disease. The association of different tests such as the complement fixation reaction (CFR), indirect hemagglutination (IHA), and IIF for IgG and IgM allowed to obtain a serologic profile of the disease that was used for its characterization worldwide over many years (4). In Brazil, work by Camargo et al. demonstrated the diagnostic efficacy of the serologic profile especially during pregnancy. The initial observation of some false positive and false negative results for T. gondii-specific lgM could be overcome by a simple pre-adsorption of the sera with commercial reagents (5).

The diagnosis of toxoplasmosis was improved by the need for automation of the tests procedures due to the 
large number of samples routinely analyzed in big laboratories, and by the introduction of more sensitive assays that abolished human errors such as the subjective interpretation of IIF results. As a matter of fact, modern technology offers many tools for the clinical laboratory that permit not only the correct diagnosis but also prevention and follow-up of the disease. Among these tools, the automated and standardized assays for anti-T. gondii specific lgG detection developed by bioMérieux S.A. and Abbott Laboratories occupy an important position. The knowledge of the specificity and sensitivity of each test principle is fundamental for the physician so that he or she can make correct decisions and patient counseling, especially during pregnancy (8). Thus, today the presence of anti T. gondii-specific $\lg \mathrm{G}$ in patient serum is considered indicative for immunity, while a negative serologic result suggests non-immunity and, therefore, means that the patient is at risk of infection when exposed to the different forms of transmission of $\mathrm{T}$. gondii.

In the present work we compared two different automated assays that detect $\mathrm{T}$. gondii-specific $\lg \mathrm{G}$. Sera which were low-reactive in the AxSYM Toxo lgG test during routine analysis in the clinical laboratory were subsequently re-evaluated by the Vidas Toxo IgG II assay. All results were interpreted according to the guidelines suggested by the manufacturers, i.e. sera with $\mathrm{RI}>3 \mathrm{UI} / \mathrm{ml}$ were considered positive in the AxSYM Toxo IgG assay, and sera with RI > $8 \mathrm{UI} / \mathrm{ml}$ were positive in the Vidas Toxo IgC II assay. Sera were considered indeterminate when their RI values were lower than $3 \mathrm{UI} / \mathrm{ml}$ and higher than $2 \mathrm{UI} / \mathrm{ml}$ (AxSYM Toxo
IgG assay), or lower than $8 \mathrm{UI} / \mathrm{ml}$ and higher than $4 \mathrm{UI} / \mathrm{ml}$ (Vidas Toxo IgG II assay).

The results shown in Table 1 demonstrate that 73 serum samples were positive in both assays. In general, the reactivity observed for the Vidas Toxo IgG II assay from bioMérieux S.A. was higher (average $39.78 \mathrm{UI} / \mathrm{ml}$ ) than those of the AxSYM Toxo lgG from Abbott (average $15.80 \mathrm{UI} / \mathrm{ml}$ ). The Figure is a graphic representation of these results. Table 2 lists the results obtained for three serum samples that were reactive in the Abbott AxSYM assay but negative in the Vidas Toxo $\lg G \mathrm{Il}$ assay from bioMérieux S.A. There are two possible explanations for these results: either false negative results for the Vidas Toxo IgG II bioMérieux S.A. or false positive results for the Abbott AxSYM Toxo lgG assay. In order to resolve the discrepant results the sera were analyzed by lgG-specific IIF and IHA. The sera were negative in both complementary assays. However, the 73 sera from Table 1 that were positive by both automated assays were also positive in IIF and IHA (data not shown), therefore suggesting that the results obtained for the three sera by the Abbott AxSYM Toxo lgC assay are really false positive.

In view of our results, the Abbott AxSYM Toxo IgG assay presented a specificity of $93 \%$, whereas the bioMérieux Vidas Toxo IgG II assay was $100 \%$ specific. These findings should alert physicians and laboratory personnel that serum samples with RI values close to the cutoff (in the Abbott AxSYM Toxo IgG assay) could provide equivocal information and, subsequently, lead to erroneous clinical patient management. We recommend, in this case, to repeat the assay and to confirm the initial results.

\section{References}

1. A shburn, D. et al. Do IgA, IgE and IgG avidity tests have any value in the diagnosis of toxoplasma infection in pregnancy? J. Clin. Pathol., 51:312-5, 1998

2. Camargo, M.E.Toxoplasmose. In: Ferreira, A.W . \& Á vila, S.L.M. (eds.). Diagnóstico Laboratorial das principais doenças infecciosas e auto-imunes. Rio de Janeiro: Guanabara Koogan, 2001, p. 278-88.

3. C amargo, M.E.; Ferreira A.W .\& Mineo, J.R. Immunoglobulin G and immunoglobulin $M$ enzyme linked immunosorbent assay and defined toxo plasmosis serological patterns. Infect. Immun., 21:55-8, 1978.

4. Camargo, M.E.; Leser, P.G. \& Leser, W .S.P. D efinição de perfis sorológicos na toxoplasmose. Importância diagnóstica e epidemiológica. Rev. Bras. Patol. Clin., 13: 113-27, 1977.

5. Camargo, M.E.; Leser, P.G \& \& Rocca, A. Rheumatoid factor as cause for false positive IgM anti toxoplasmose-fluorescent tests. A technique for specific results. Rev. Inst. Med. Trop. São Paulo, 33: 310-3, 1972
6. Cozon, G.J.N . et al. Estimation of the avidity of immunoglobulin $G$ for routine diagnosis of chronic Toxoplasma gondii infection in pregnant women. Eur. J. Clin. Microbiol. Infect. Dis.,17: 32-6, 1998.

7. Suzuki, L.A.; Rocha, R.J. \& Rossi, C.L. Evaluation of serological markers for the diagno sis of acute acquired toxo plasmosis. J. Med. M icrobiol., 50: 62-70, 2001.

8.W ilson, M. et al. Evaluation of six commercial kits for detection of human immunoglobulin $\mathrm{M}$ antibodies to Toxoplasma gondii. J. Clin. M icrobiol., 35: 3112-5, 1997.

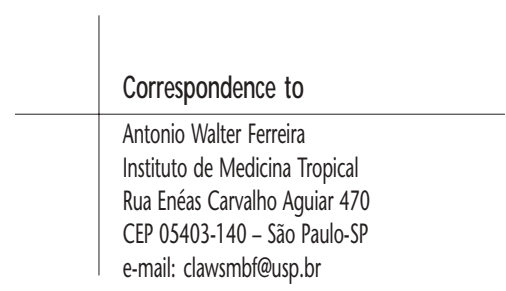

